\title{
OPTIMALISASI PERTUMBUHAN DAN HASIL EDAMAME (Glycine max L. Merril) MELALUI PEMBERIAN PUPUK NITROGEN DAN EKSTRAK TAUGE KACANG HIJAU
}

\section{Growth and Production of Edamame (Glycine max L. Merril) Through Application of Nitrogen Fertilizer and Mung Bean Sprout Extract}

\author{
Rahman ${ }^{1}$, Oktavianus Lumban Tobing ${ }^{1 \mathrm{a}}$, Setyono ${ }^{1}$ \\ Jurusa Agroteknologi, Fakultas Pertanian Universitas Djuanda Bogor \\ Jalan Tol Ciawi No. 1 Kotak Pos 35 Bogor 16720 \\ ${ }^{a}$ Korespondensi: Oktavianus Lumban Tobing, E-mail: oktavianus@unida,ac.id
}

Telp : 081328789829

\begin{abstract}
ABSTRAK
Penelitian ini dilakukan di kebun percobaan Agroteknologi Universitas Djuanda Bogor mulai bulan Juli 2018 sampai dengan bulan September 2018. Penelitian ini bertujuan untuk mengetahui pengaruh pemberian pupuk $\mathrm{N}$ dan ekstrak tauge kacang hijau terhadap pertumbuhan dan produksi tanaman kedelai edamame. Rancangan percobaan yang digunakan adalah rancangan acak lengkap faktorial. Faktor pertama adalah dosis pupuk dengan empat taraf yaitu tanpa $\mathrm{N}(0 \mathrm{~kg} \mathrm{~N} / \mathrm{ha})$, pupuk $\mathrm{N}$ setengah rekomendasi $(34,5 \mathrm{~kg} \mathrm{~N} / \mathrm{ha})$, pupuk $\mathrm{N}$ sesuai rekomendasi $(69 \mathrm{~kg} \mathrm{~N} / \mathrm{ha})$, pupuk $\mathrm{N}$ satu setengah rekomendasi $(103,5 \mathrm{~kg} \mathrm{~N} / \mathrm{ha})$. Faktor kedua adalah konsentrasi ekstrak tauge kacang hijau dengan empat taraf yaitu tanpa ekstrak tauge kacang hijau (0g tauge/l air), ekstrak tauge kacang hijau setengah rekomendasi (75g tauge/l air), ekstrak tauge kacang hijau sesuai rekomendasi (150g tauge/l air) dan ekstrak tauge kacang hijau satu setengah rekomendasi (225g tauge/l air). Hasil penelitian menunjukkan bahwa dosis pupuk $\mathrm{N}$ berpengaruh nyata pada luas daun terluas. Konsentrasi ekstrak tauge kacang hijau berpengaruh nyata pada jumlah tunas 6 dan 7 MST.

Kata Kunci : kedelai edamame, pupuk N, tauge kacang hijau
\end{abstract}

\begin{abstract}
This study was conducted at the experiment garden of Agrotechnology Department, Djuanda University, Bogor, from July to September 2018. The study was aimed at assessing the effects of the application of nitrogen fertilizer and mung bean sprout extract on the growth and production of edamame (Glycine max L. Merril) plants. The experimental design used was a factorial completely randomized design. The first factor is the dose of $N$ fertilizer with four levels, namely without $N(0 \mathrm{~kg} \mathrm{~N} / \mathrm{ha})$, a half recommendation of $N$ fertilizer $(34.5 \mathrm{~kg} \mathrm{~N} / \mathrm{ha})$, one recommendation of $\mathrm{N}$ fertilizer (69 $\mathrm{kg} \mathrm{N} / \mathrm{ha})$, and one and a half recommendation of $\mathrm{N}$ fertilizer $(103.5 \mathrm{~kg} \mathrm{~N} / \mathrm{ha}$ ). The second factor is the concentration of mung bean sprout extract with four levels, namely without mung bean sprout extract ( $0 \mathrm{~g}$ tauge extract / l water), a half recommendation of mung bean sprout extract ( $75 \mathrm{~g}$ tauge extract/ $l$ water), one recommendation of mung bean sprout extract (150g tauge extract / $l$ water) and one and a half recommendation of mung bean sprout extract (225g tauge extract/ $l$ water). The results showed that the dose of $N$ fertilizer significantly affected the widest leaf area. The concentration of mung bean sprout extract significantly affected the number of shoots at 6 and 7 weeks after planting (MST).
\end{abstract}

Keywords: edamame soybean, $N$ fertilizer, mung bean sprout 


\section{PENDAHULUAN}

Seiring meningkatnya pengetahuan gizi masyarakat, sehingga saat ini kedelai kembali menjadi perhatian. Terlebih lagi sejak kepopuleran edamame (kedelai Jepang) sebagai camilan. Kedelai edamame merupakan jenis tanaman yang termasuk ke dalam kategori sayuran (green soybean vegetable). Di negara asalnya yaitu Jepang, edamame atau gojiru dijadikan sebagai sayuran serta camilan kesehatan (Budiarto 2003).

Edamame mengandung antioksidan dan isoflavon. Konsumsi makanan yang kaya akan antioksidan dapat menguatkan sistem imun tubuh dan mengurangi risiko kanker. Isoflavon juga terbukti mengurangi risiko kanker prostat dan kanker payudara, mencegah penyakit jantung, menurunkan tekanan darah, serta mengurangi gangguan saat menopause. Setengah cangkir edamame (75 g) hanya terkandung 100 kalori, sehingga baik untuk diet sehari-hari (Abbas dan Akmadi 2010).

Kedelai edamame mengandung nilai gizi yang cukup tinggi, setiap $100 \mathrm{~g}$ biji mengandung $582 \mathrm{kkal}$, protein $11,4 \mathrm{~g}$, karbohidrat 7,4 g, lemak 6,6 g, vitamin A atau karotin $100 \mathrm{mg}, \mathrm{B} 1$ 0,27 mg, B2 0,14 $\mathrm{mg}$, B3 $1 \mathrm{mg}$, dan vitamin C 27, serta mineral-mineral seperti fosfor $140 \mathrm{mg}$, kalsium 70 mg, besi 1,7 mg, dan kalium 140 mg (Johnson et al 1999).

Kedelai (Glycine max (L.) Merr.) merupakan salah satu komoditas pangan bergizi tinggi dan sumber protein nabati yang rendah kolesterol dengan harga terjangkau (Atman 2006). Berdasarkan data Badan Pusat Statistik (2011), produksi kedelai lokal hanya 851.286 ton atau 29 persen dari total kebutuhan nasional. Total kebutuhan kedelai nasional adalah 2,2 juta ton, sehingga Indonesia harus mengimpor kedelai sebanyak 2.087.986 ton untuk memenuhi 71 persen kebutuhan kedelai dalam negeri. Jumlah tersebut akan diserap untuk pangan 83,7 persen, industri kecap, tauco, dan lainnya 14,7 persen, benih 1,2 persen, dan untuk pakan 0,4 persen. Impor kedelai terbesar Indonesia berasal dari
Amerika Serikat dengan jumlah 1.847.900 ton.

Edamame merupakan tanaman potensial yang perlu dikembangkan karena memiliki produktivitas yang tinggi, umur relatif lebih pendek, ukuran polongnya lebih besar, dan rasanya lebih manis (Rukmana 1996). Selain itu rata-rata produksi edamame sebesar 3,5 ton/ha, yang lebih tinggi dibandingkan dengan produksi tanaman kedelai biasa yang memiliki ratarata produksi 1,7 - 3,2 ton/ha. Selain itu, peluang ekspor edamame terutama ke negara Jepang masih terbuka, hal ini karena permintaan edamame di negara tersebut belum dapat dipenuhi.

Kebutuhan pangsa pasar tersebut memerlukan upaya peningkatan produksi baik kualitas maupun kuantitas sehingga dapat bersaing dengan negara pengekspor lainnya terutama China dan Taiwan yang merupakan negara pengekspor terbesar edamame.

Menurut Fahmi et al. (2014), berbagai usaha yang dapat dilakukan untuk meningkatkan produksi kedelai di Indonesia, baik secara ekstensifikasi maupun secara intensifikasi, salah satu cara intensifikasi adalah dengan pemupukan yang tepat. Menurut Suryana (2012), pemberian pupuk dengan dosis yang berlebihan dapat menyebabkan keracunan bagi tanaman. Peningkatan dosis pupuk NPK mula-mula meningkatkan pertumbuhan dan hasil kedelai, setelah tanggapan tersebut mencapai maksimum maka pertumbuhan dan hasil kedelai akan menurun seiring dengan peningkatan dosis pupuk yang diberikan.

Salah satu upaya yang dapat meningkatkan produksi kedelai edamame yaitu pemupukan. Pupuk yang diberikan dapat berupa pupuk organik maupun pupuk anorganik. Dosis pupuk anjuran pada tanaman kedelai secara umum adalah Urea 50-85 kg/ha, SP-36 sekitar 90-150 kg/ha, dan $\mathrm{KCl} 25-50 \mathrm{~kg} / \mathrm{ha}$ (Kartahadimaja et al 2010). Dosis pupuk anjuran untuk tanaman edamame adalahUrea $150 \mathrm{~kg} / \mathrm{ha}, \mathrm{SP}-36150$ 
$\mathrm{kg} / \mathrm{ha}, \mathrm{KCl} 100 \mathrm{~kg} / \mathrm{ha}$ atau $400 \mathrm{~kg} \mathrm{~N}, \mathrm{P}$, K/ha (Departemen Pertanian 2012).

Selain pupuk kimia upaya lain untuk meningkatkan produksi edamame dapat dilakukan dengan memberikan zat pengatur tumbuh (ZPT). Zat pengatur tumbuh tanaman berperan penting dalam mengontrol proses biologi dalam jaringan tanaman (Davies 1995). Perannya antara lain mengatur kecepatan pertumbuhan dari masing-masing jaringan dan mengintegrasikan bagian-bagian tersebut guna menghasilkan bentuk yang kita kenal sebagai tanaman. Menurut George (1993) aktivitas zat pengatur tumbuh di dalam pertumbuhan tergantung dari jenis, struktur kimia, konsentrasi, genotipe tanaman serta fase fisiologi tanaman. Salah satu bahan yang dapat digunakan sebagai sumber ZPT yaitu ekstrak tauge kacang hijau.

Menurut Amilah dan Astuti (2006), komposisi gizi yang terdapat pada esktrak tauge kacang hijau dalam $100 \mathrm{~g}$ di antaranya yaitu, kalori 23 (kal), protein 2,9 (g), lemak 0,2 (g), hidrat arang 4,1 (g), kalsium $29(\mathrm{mg})$, fosfor $69(\mathrm{mg})$, besi 0,8 (mg), vitamin A 10 (IU), vitamin B 0,07 (mg), vitamin C 15 (mg).

Menurut Widiastoety dan Nurmalinda (2010), taoge kacang hijau mengandung zat pengatur tumbuh auksin yang berfungsi sebagai stimulan dalam memperlancar proses metabolism, sehingga dapat meningkatkan pertumbuhan dan perkembangan tanaman. Hasil penelitian Amilah dan Astuti (2006), menunjukkan bahwa penggunaan ekstrak tauge kacang hijau $150 \mathrm{~g} / \mathrm{l}$ memberikan hasil yang tertinggi pada tanaman anggrek bulan. Pengaruh ekstrak tauge kacang hijau pada tanaman edamame belum diketahui, sehingga penelitian ini perlu dilakukan.

\section{BAHAN DAN METODE}

Penelitian ini dilakukan mulai bulan Juli 2018 sampai dengan bulan September 2018. Benih edamame diperoleh dari petani di Megamendung Kabupaten Bogor. Penanaman edamame dilakukan di Kebun Percobaan Program Studi Agroteknologi
Universitas Djuanda Bogor. Alat yang digunakan meliputi alat pengolah tanah, polibag, alat ukur, timbangan, alat penyiraman. Bahan yang digunakan adalah benih tanaman kacang kedelai edamame dengan menggunakan media tanam tanah, arang sekam dan berbagai dosis pupuk urea.

Penelitian ini menggunakan rancangan acak lengkap (RAL) faktorial, perlakuan terdiri atas 2 faktor dan 3 ulangan. Faktor pertama adalah pemberian pupuk Nitrogen dengan 4 taraf $(0 \mathrm{~kg} \mathrm{~N} / \mathrm{ha}$, $34,5 \mathrm{~kg} \mathrm{~N} / \mathrm{ha}, 69 \mathrm{~kg} \mathrm{~N} / \mathrm{ha}, 103,5 \mathrm{~kg} \mathrm{~N} / \mathrm{ha}$ ). Faktor kedua adalah pemberian konsentrasi ekstrak tauge kacang hijau yang terdiri atas 4 taraf (0 g/l, $75 \mathrm{~g} / \mathrm{l}, 150 \mathrm{~g} / \mathrm{l}, 225 \mathrm{~g} / \mathrm{l})$. Perhitungan di atas menggunakan asumsi kedalaman solum tanah $20 \mathrm{~cm}$, berat jenis tanah 1, dan bobot tanah per polibag $12 \mathrm{~kg}$. Secara keseluruhan terdapat 16 kombinasi perlakuan yang diulang tiga kali, sehingga terdapat 48 satuan percobaan. Setiap satuan percobaan menggunakan tiga polibeg, sehingga jumlah seluruhnya terdapat 144 satuan amatan.

Model linier untuk percobaan yang digunakan adalah sebagai berikut:

Pengaruh perlakuan diuji dengan uji

F (analisis ragam). Jika perlakuan berpengaruh nyata maka dilanjutkan dengan uji jarak berganda Duncan (DMRT). Semua pengujian menggunakan taraf nyata $5 \%$.

\section{Penanaman}

Sebelum penelitian terlebih dahulu dilakukan pembersihan lahan dari gulma dan sisa-sisa tanaman dengan menggunakan cangkul dan membersihkan sampah pada lahan. Penanaman menggunakan tanah yang ada di lahan percobaan kampus. Tanah yang digunakan dikeringanginkan dan diayak. Masingmasing polybag ditanam 1 benih dan diberikan jarak tanam antar polybag sekitar $20 \times 20 \mathrm{~cm}$. 


\section{Pemupukan}

Pemberian pupuk $\mathrm{N}$ dan ekstrak tauge kacang hijau pada tanaman kedelai edamame dilakukan pada umur 2 MST dan 3 MST. Ekstrak tauge kacang hijau dihaluskan terlebih dahulu dan direndam pada 11 air sesuai dengan konsentrasinya, kemudian didiamkan selama 2 hari.

\section{Pemeliharaan}

Pemeliharaan tanaman edamame meliputi penyiraman dan penyiangan. Penyiraman memanfaatkan air hujan. Apabila tidak ada hujan maka penyiraman dilakukan setiap pagi dan sore hari. Pada waktu tanaman berumur 2 MST dan 3 MST penyiraman dilakukan dengan menggunakan ekstrak tauge kacang hijau pada saat cuaca cerah. Penyiangan dilakukan dengan cara manual.

\section{Panen}

Kegiatan panen dimulai pada 8 minggu setelah tanam (MST) berdasarkan tingkat kesiapan tanaman untuk dipanen.
Tanaman dipanen tidak perlu menggunakan alat cukup dipetik pada kedelai yang sudah siap dipanen.

\section{Peubah yang Diamati}

Peubah komponen pertumbuhan yang diamati berupa tinggi tanaman, jumlah daun, luas daun terluas dengan metode gravimetri, jumlah polong (buah), Peubah komponen hasil meliputi bobot basah dan kering brangkasan per tanaman, bobot basah dan kering polong per tanaman, bobot basah dan kering tajuk dan akar. Bobot kering ditimbang setelah dioven pada suhu $70^{\circ} \mathrm{C}$ selama 2 hari (setelah bobot konstan).

\section{HASIL DAN PEMBAHASAN Hasil}

Dosis pupuk N, konsentrasi ekstrak tauge kacang hijau dan interaksi keduanya tidak berpengaruh terhadap tinggi tanaman kedelai edamame pada 3-7MST. Nilai ratarata tinggi tanaman pada masing-masing perlakuan dapat dilihat pada Tabel 1 .

Tabel 1 Tinggi tanaman edamame pada umur 3-7 MST

\begin{tabular}{llllll}
\hline \multirow{2}{*}{ Perlakuan } & \multicolumn{5}{c}{ Tinggi Tanaman $(\mathrm{cm})$} \\
\cline { 2 - 6 } \multicolumn{1}{c}{ Pupuk Urea } & 3 MST & 4 MST & 5 MST & 6 MST & MST \\
\cline { 2 - 6 } $0 \mathrm{~kg} \mathrm{~N} / \mathrm{ha}$ & 36,81 & 48,69 & 52,56 & 54,17 & 54,89 \\
$34,5 \mathrm{~kg} \mathrm{~N} / \mathrm{ha}$ & 37,31 & 49,64 & 53,14 & 55,36 & 56,03 \\
$69 \mathrm{kgN} / \mathrm{ha}$ & 37,33 & 50,06 & 53,11 & 54,42 & 55,03 \\
$103,5 \mathrm{kgN} / \mathrm{ha}$ & 37,81 & 50,89 & 53,94 & 56,08 & 56,53 \\
\hline Ekstrak Tauge & & & & \\
Kacang Hijau & 36,72 & 49,17 & 52,69 & 54,28 & 55,39 \\
$0 \mathrm{~g} / \ell$ air & 37,64 & 49,97 & 52,97 & 54,61 & 55,53 \\
$75 \mathrm{~g} / \ell$ air & 36,75 & 49,53 & 52,81 & 54,56 & 54,94 \\
$150 \mathrm{~g} / \ell$ air & 38,14 & 50,61 & 54,28 & 56,58 & 56,61 \\
$225 \mathrm{~g} / \ell$ air & & & & & \\
\hline
\end{tabular}

Jumlah Daun Kedelai Edamame

Dosis pupuk N, konsentrasi ekstrak tauge kacang hijau dan interaksi keduanya tidak memberikan pengaruh yang signifikan terhadap jumlah daun pada tanaman kedelai edamame. Rata-rata jumlah daun pada berbagai perlakuan dapat dilihat pada Tabel 2. 
Tabel 2 Jumlah daun tanaman edamame pada umur 3 - 7 MST

\begin{tabular}{lccccc}
\hline \multirow{2}{*}{ Perlakuan } & \multicolumn{5}{c}{ Jumlah daun (helai) } \\
\cline { 2 - 6 } & 3 MST & 4 MST & 5 MST & 6 MST & 7 MST \\
\hline \multicolumn{1}{c}{ Pupuk Urea } & & & & & \\
$0 \mathrm{~kg} \mathrm{~N} / \mathrm{ha}$ & 4,06 & 6,06 & 6,42 & 6,58 & 6,58 \\
$34,5 \mathrm{~kg}$ N/ha & 4,17 & 6,42 & 6,47 & 6,67 & 6,67 \\
$69 \mathrm{kgN} / \mathrm{ha}$ & 4,25 & 6,44 & 6,47 & 6,67 & 6,67 \\
$103,5 \mathrm{kgN} / \mathrm{ha}$ & 4,31 & 6,22 & 6,50 & 6,69 & 6,69 \\
\hline Ekstrak Tauge & & & & & \\
Kacang Hijau & 4,11 & 6,25 & 6,36 & 6,61 & 6,61 \\
$0 \mathrm{~g} / \ell$ air & 4,14 & 6,31 & 6,50 & 6,64 & 6,64 \\
$75 \mathrm{~g} / \ell$ air & 4,17 & 6,28 & 6,44 & 6,69 & 6,69 \\
$150 \mathrm{~g} / \ell$ air & 4,36 & 6,31 & 6,56 & 6,67 & 6,67 \\
$225 \mathrm{~g} / \ell$ air & & & & & \\
\end{tabular}

\section{Jumlah Anak Daun Kedelai Edamame}

Pemberian dosis pupuk $\mathrm{N}$ konsentrasi ekstrak tauge kacang hijau dan interaksi keduanya tidak berpengaruh nyata terhadap jumlah anak daun kedelai edamame. Hasil rata-rata jumlah anak daun terhitung dari 3 MST sampai dengan 7 MST dapat dilihat pada Tabel 3.

Tabel 3 Jumlah anak daun tanaman kedelai edamame pada umur 3 - 7 MST

\begin{tabular}{lccccc}
\hline \multirow{2}{*}{ Perlakuan } & \multicolumn{5}{c}{ Jumlah anak daun (helai) } \\
\cline { 2 - 6 } & 3 MST & 4 MST & 5 MST & 6 MST & 7 MST \\
\hline \multicolumn{1}{c}{ Pupuk Urea } & & & & & \\
$0 \mathrm{~kg} \mathrm{~N} / \mathrm{ha}$ & 12,17 & 18,17 & 19,25 & 19,75 & 19,75 \\
$34,5 \mathrm{~kg} \mathrm{~N} / \mathrm{ha}$ & 12,50 & 19,25 & 19,42 & 20,00 & 20,00 \\
$69 \mathrm{kgN} / \mathrm{ha}$ & 12,75 & 19,33 & 19,42 & 20,00 & 20,00 \\
$103,5 \mathrm{kgN} / \mathrm{ha}$ & 12,92 & 18,67 & 19,50 & 20,08 & 20,08 \\
\hline \multicolumn{1}{c}{ Ekstrak Tauge } & & & & & \\
Kacang Hijau & 12,33 & 18,75 & 19,08 & 19,83 & 19,83 \\
$0 \mathrm{~g} / \ell$ air & 12,42 & 18,92 & 19,50 & 19,92 & 19,92 \\
$75 \mathrm{~g} / \ell$ air & 12,50 & 18,83 & 19,33 & 20,08 & 20,08 \\
$150 \mathrm{~g} / \ell$ air & 13,08 & 18,92 & 19,67 & 20,00 & 20,00 \\
$225 \mathrm{~g} / \ell$ air & & & & & \\
\hline
\end{tabular}

\section{Jumlah Tunas Kedelai Edamame}

Jumlah tunas pada 6 dan 7MST dipengaruhi oleh ekstrak tauge kacang hijau, tetapi tidak dipengaruhi oleh pupuk urea dan interaksi antara pupuk urea dan ekstrak tauge kacang hijau. Hasil uji DMRT menunjukkan jumlah tunas pada perlakuan ekstrak tauge kacang hijau konsentrasi $0 \mathrm{~g} / \mathrm{l}$ tidak berbeda nyata dengan konsentrasi 50g/l dan konsentrasi 75g/l tetapi berbeda nyata dengan konsentrasi $225 \mathrm{~g} / \mathrm{l}$. Rata-rata jumlah tunas dari berbagai perlakuan dapat dilihat pada Tabel 4. 
Tabel 4 Jumlah tunas tanaman edamame pada umur 3 - 7 MST

\begin{tabular}{lccccc}
\hline \multirow{2}{*}{ Perlakuan } & \multicolumn{5}{c}{ Jumlah tunas } \\
\cline { 2 - 6 } & $3 \mathrm{MST}$ & 4 MST & $5 \mathrm{MST}$ & $6 \mathrm{MST}$ & $7 \mathrm{MST}$ \\
\hline \multicolumn{1}{c}{ Pupuk Urea } & & & & \\
$0 \mathrm{~kg}$ N/ha & 2,06 & 2,72 & 4,11 & 5,14 & 5,14 \\
$34,5 \mathrm{~kg} \mathrm{~N} / \mathrm{ha}$ & 2,22 & 2,92 & 4,14 & 5,17 & 5,17 \\
$69 \mathrm{kgN} / \mathrm{ha}$ & 2,25 & 3,25 & 4,39 & 5,28 & 5,28 \\
$103,5 \mathrm{kgN} / \mathrm{ha}$ & 2,08 & 3,00 & 4,14 & 5,22 & 5,22 \\
\hline Ekstrak Tauge & & & & & \\
Kacang Hijau & 1,92 & 2,81 & 3,97 & $4,97 \mathrm{a}$ & $4,97 \mathrm{a}$ \\
$0 \mathrm{~g} / \ell$ air & 2,11 & 2,94 & 4,06 & $5,02 \mathrm{a}$ & $5,02 \mathrm{a}$ \\
$75 \mathrm{~g} / \ell$ air & 2,06 & 2,89 & 4,11 & $5,08 \mathrm{a}$ & $5,08 \mathrm{a}$ \\
$150 \mathrm{~g} / \ell$ air & 2,53 & 3,25 & 4,64 & $5,72 \mathrm{~b}$ & $5,72 \mathrm{~b}$ \\
$225 \mathrm{~g} / \ell$ air & & & & & \\
&
\end{tabular}

\section{Jumlah Polong}

Dosis pupuk N, konsentrasi ekstrak tauge kacang hijau dan interaksi keduanya tidak berpengaruh nyata terhadap jumlah polong tanaman kedelai edamame. Ratarata jumlah polong terhitung dari 6MST sampai dengan $8 \mathrm{MST}$ dapat dilihat pada Tabel 5.

Tabel 5 Jumlah polong tanaman edamame pada umur 6 - 8 MST

\begin{tabular}{lccc}
\hline \multirow{2}{*}{ Perlakuan } & \multicolumn{3}{c}{ Jumlah polong } \\
\cline { 2 - 4 } \multicolumn{1}{c}{ Pupuk Urea } & 6 MST & 7 MST & 8 MST \\
\cline { 2 - 4 } $0 \mathrm{~kg} \mathrm{~N} / \mathrm{ha}$ & 15,89 & 22,97 & 27,19 \\
$34,5 \mathrm{~kg} \mathrm{~N} / \mathrm{ha}$ & 17,42 & 23,39 & 28,14 \\
$69 \mathrm{kgN} / \mathrm{ha}$ & 17,28 & 23,81 & 28,44 \\
$103,5 \mathrm{kgN} / \mathrm{ha}$ & 17,67 & 23,42 & 28,50 \\
\hline Ekstrak Tauge Kacang Hijau & & & \\
$0 \mathrm{~g} / \ell$ air & 16,08 & 22,25 & 26,97 \\
$75 \mathrm{~g} / \ell$ air & 17,39 & 23,36 & 28,53 \\
$150 \mathrm{~g} / \ell$ air & 16,83 & 23,19 & 27,92 \\
$225 \mathrm{~g} / \ell$ air & 17,94 & 24,78 & 28,86 \\
\hline
\end{tabular}

\section{Luas Daun Terluas}

Luas daun terluas dipengaruhi oleh pupuk $\mathrm{N}$, tetapi tidak dipengaruhi oleh ekstrak tauge kacang hijau dan interaksi antara pupuk $\mathrm{N}$ dan ekstrak tauge kacang hijau. Uji DMRT menghasilkan bahwa luas daun terluas pada perlakuan pupuk $\mathrm{N}$ dengan dosis $0 \mathrm{~kg} \mathrm{~N} / \mathrm{ha}$ tidak berbeda nyata dengan dosis $34,5 \mathrm{~kg} \mathrm{~N} / \mathrm{ha}$, tetapi berbeda nyata pada dosis $69 \mathrm{~kg}$ N/ha dan $103,5 \mathrm{~kg}$ N/ha (Tabel 6). 
Tabel 6 Rata-rata luas daun terluas

\begin{tabular}{lc}
\hline \multicolumn{1}{c}{ Perlakuan } & Luas Daun Terluas $\left(\mathrm{cm}^{2}\right)$ \\
\hline Pupuk Urea & \\
$0 \mathrm{~kg} \mathrm{~N} / \mathrm{ha}$ & $136,01 \mathrm{a}$ \\
$34,5 \mathrm{~kg} \mathrm{~N} / \mathrm{ha}$ & $157,407 \mathrm{ab}$ \\
$69 \mathrm{kgN} / \mathrm{ha}$ & $171,48 \mathrm{~b}$ \\
$103,5 \mathrm{kgN} / \mathrm{ha}$ & $200,55 \mathrm{c}$ \\
\hline \multicolumn{1}{c}{ Ekstrak Tauge Kacang Hijau } \\
$0 \mathrm{~g} / \ell$ air & 161,67 \\
$75 \mathrm{~g} / \ell$ air & 162,69 \\
$150 \mathrm{~g} / \ell$ air & 163,15 \\
$225 \mathrm{~g} / \ell$ air & 177,96 \\
\hline Keterangan: Nilai rata-rata pada kolom yang sama diikuti huruf yang sama tidak berbeda nyata \\
$\quad$ menurut uji DMRT pada taraf $5 \%$
\end{tabular}

Dosis pupuk N, ekstrak tauge tauge kacang hijau dan interaksi kedua kacang hijau dan interaksi kedua perlakuan tidak berpengaruh nyata terhadap bobot basah dan akar basah dan kering kedelai edamame. Pemberian pupuk N, ekstrak perlakuan tidak berpengaruh nyata terhadap bobot basah dan kering polong tanaman kedelai edamame (Tabel 7).

Tabel 7 Bobot basah dan kering akar dan polong edamame

\begin{tabular}{|c|c|c|c|c|}
\hline \multirow{2}{*}{ Perlakuan } & \multicolumn{2}{|c|}{ Bobot akar (g) } & \multicolumn{2}{|c|}{ Bobot Polong (g) } \\
\hline & Basah & Kering & Basah & Kering \\
\hline \multicolumn{5}{|l|}{ Pupuk Urea } \\
\hline $0 \mathrm{~kg} \mathrm{~N} / \mathrm{ha}$ & 3,76 & 1,84 & 56,25 & 17,44 \\
\hline $34,5 \mathrm{~kg} \mathrm{~N} / \mathrm{ha}$ & 3,89 & 1,87 & 58,19 & 18,45 \\
\hline $69 \mathrm{kgN} / \mathrm{ha}$ & 4,06 & 1,90 & 58,82 & 18,76 \\
\hline $103,5 \mathrm{kgN} / \mathrm{ha}$ & 4,08 & 2,04 & 59,85 & 18,86 \\
\hline \multicolumn{5}{|c|}{ Ekstrak Tauge Kacang Hijau } \\
\hline $0 \mathrm{~g} / \ell$ air & 3,67 & 1,81 & 55,59 & 17,85 \\
\hline $75 \mathrm{~g} / \ell$ air & 3,84 & 1,86 & 58,76 & 18,12 \\
\hline $150 \mathrm{~g} / \ell$ air & 3,97 & 1,94 & 58,93 & 18,38 \\
\hline $225 \mathrm{~g} / \ell$ air & 4,31 & 2,03 & 59,83 & 19,15 \\
\hline
\end{tabular}


Dosis pupuk $\mathrm{N}$, ekstrak tauge kacang hijau, dan interaksi kedua perlakuan tidak berpengaruh nyata terhadap bobot basah dan kering tajuk serta brangkasan tanaman kedelai edamame. Rata-rata bobot basah dan kering tajuk dan brangkasan dapat dilihat pada Tabel 8.

Tabel 8. Bobot tajuk dan brangkasan basah dan kering edamame

\begin{tabular}{|c|c|c|c|c|}
\hline \multirow{2}{*}{ Perlakuan } & \multicolumn{2}{|c|}{ Bobot tajuk (g) } & \multicolumn{2}{|c|}{ Bobot brangkasan $(\mathrm{g})$} \\
\hline & Basah & Kering & basah & kering \\
\hline Pupuk Urea & & & & \\
\hline $0 \mathrm{~kg} \mathrm{~N} / \mathrm{ha}$ & 24,43 & 9,77 & 84,44 & 29,05 \\
\hline $34,5 \mathrm{~kg} \mathrm{~N} / \mathrm{ha}$ & 24,46 & 9,79 & 86,55 & 29,93 \\
\hline $69 \mathrm{kgN} / \mathrm{ha}$ & 24,58 & 9,83 & 87,46 & 30,38 \\
\hline $\begin{array}{l}103,5 \mathrm{kgN} / \mathrm{ha} \\
\text { Ekstrak Tauge Kacang Hijau }\end{array}$ & 24,60 & 9,86 & 89,35 & 30,75 \\
\hline $0 \mathrm{~g} / \ell$ air & 23,98 & 9,59 & 84,05 & 29,26 \\
\hline $75 \mathrm{~g} / \ell$ air & 24,21 & 9,68 & 86,80 & 29,67 \\
\hline $150 \mathrm{~g} / \ell$ air & 24,80 & 9,93 & 87,70 & 30,24 \\
\hline $225 \mathrm{~g} / \ell$ air & 25,10 & 10,04 & 89,23 & 30,94 \\
\hline
\end{tabular}

\section{Pembahasan}

Nitrogen memiliki peran penting dalam produksi klorofil dan sintetis protein. Ketika kekurangan nitrogen, daun tanaman menjadi kuning sehingga pertumbuhan tanaman terhambat (Lazureanu et al 2007). Pemupukan dengan konsentrasi tepat akan memberikan hasil optimal pada tanaman, selama faktor-faktor lingkungan seperti suhu, cahaya, dan lain-lain juga berada dalam kondisi optimal.

Pada penelitian ini dosis urea $(\mathrm{N})$ berpengaruh terhadap luas daun terluas. Hasil ini sejalan dengan Humphries dan Wheeler (1963) yang menyatakan bahwa pemupukan nitrogen mempunyai pengaruh yang nyata terhadap perluasan daun, terutama pada lebar dan luas daun, walaupun jumlah dan ukuran daun dipengaruhi juga oleh genotipe dan lingkungan. Follet dan Muphy (1989) menambahkan bahwa nitrogen dapat memicu pertumbuhan daun kedelai dan dari hasil fotosintesis akan menghasilkan gula melalui proses respirasi di sel.

Fotosintat yang dihasilkan daun akan berpengaruh pada pembentukan daun dan organ tanaman yang lain. Menurut Sitompul dan Guritno (1995), tanaman yang mempunyai daun yang lebih banyak pada awal pertumbuhannya, akan lebih cepat tumbuh karena kemampuan menghasilkan fotosintat yang lebih tinggi dari tanaman dengan jumlah daun yang lebih rendah. Jumlah daun tanaman akan mempengaruhi pertumbuhan jaringan tanaman yang lain.

Ningsih et al. (2005) menyatakan bahwa pemberian pupuk anorganik 0,125 $\mathrm{g} / \mathrm{tanaman}$ menunjukkan peningkatan pertumbuhan pada tinggi tanaman dan luas daun tanaman kedelai pada umur 35 hari setelah tanam. Hal ini sesuai dengan hasil penelitian ini, pemberian Urea dengan dosis $0,135 \mathrm{~g}$ urea/tanaman menghasilkan luas daun terluas dibandingkan dengan perlakuan lain.

Menurut Gardner et al (1991) nitrogen berpengaruh terhadap tinggi tanaman dan pertumbuhan akar. Hal ini tidak sejalan pada hasil penelitian ini, dosis urea $(\mathrm{N})$ tidak berpengaruh terhadap tinggi tanaman, jumlah daun, diameter batang, dan pertumbuhan akar tanaman kedelai edamame. Hal ini diduga berkaitan dengan sifat dari urea yang mudah menguap dan tercuci dari air. Hal ini sejalan dengan Bara dan Chozin (2009) yang menyatakan bahwa frekuensi pemberian pupuk urea secara bertahap tidak berpengaruh terhadap tinggi tanaman, jumlah daun dan diameter batang. Lingga dan Marsono (2008) menyatakan urea mudah menguap, larut dan tercuci sehingga hanya $30-50 \%$ saja yang dimanfaatkan oleh tanaman.

Perlakuan ekstrak tauge kacang hijau memberikan pengaruh yang nyata terhadap 
jumlah tunas tanaman kedelai edamame. Zat pengatur tumbuh tanaman berperan penting dalam mengontrol proses biologi dalam jaringan tanaman (Davies 1995, Gaba 2005). Perannya antara lain mengatur kecepatan pertumbuhan dari masing-masing jaringan dan mengintegrasikan bagian-bagian tersebut guna menghasilkan bentuk yang dikenal sebagai tanaman. Menurut George (1993) aktivitas zat pengatur tumbuh di dalam pertumbuhan tergantung dari jenis, struktur kimia, konsentrasi, genotipe tanaman serta fase fisiologi tanaman.

Pada penelitian ini konsentrasi ekstrak tauge kacang hijau berpengaruh terhadap jumlah tunas kedelai edamame. Hal ini sejalan dengan Hadi (2006) yang menyatakan bahwa penambahan ekstrak tauge kacang hijau 37,5 $\mathrm{g} / \mathrm{l}$ memberikan hasil yang baik terhadap tinggi tunas anggrek Dendrobium, sedangkan pada penelitian ini dosis yang memberikan jumlah tunas terbanyak adalah $225 \mathrm{~g} / \mathrm{l}$.

Menurut Widiastoety dan Nurmalinda (2010), tauge kacang hijau mengandung zat pengatur tumbuh auksin yang berfungsi sebagai stimulan dalam memperlancar proses metabolisme, sehingga dapat meningkatkan pertumbuhan dan perkembangan tanaman.

\section{Kesimpulan}

\section{KESIMPULAN}

Dari kegiatan penelitian ini dapat disimpulkan bahwa:

- Pemberian pupuk $\mathrm{N}$ berpengaruh nyata terhadap luas daun terluas pada tanaman kedelai edamame

- Pemberian ekstrak tauge kacang hijau berpengaruh nyata pada jumlah tunas pada tanaman kedelai edamame.

\section{Implikasi Kebijakan}

Pemberian dosis $\mathrm{N}$ dan konsentrasi ekstrak tauge kacang hijau jika ditingkatkan dan frekuensi pemberiannya lebih banyak dapat memberikan respon pada pertumbuhan dan produksi tanaman kedelai.

\section{DAFTAR PUSTAKA}

Abbas, Akmadi. 2010. Rancang Bangun Prototipe Mesin Pelecet Kulit Polong Kedelai Basah dalam Menunjang Proses Pengolahan Kedelai Sayur Mukimame. Subang: Balai Besar Pengembangan Teknologi Tepat Guna LIPI.

Amilah, Astuti. 2006. Pengaruh konsentrasi ekstrak tauge dan kacang hijau pada media vacin and went (VW) terhadap Pertumbuhan Kecambah Anggrek Bulan Phalaenopsis amabilis L. Bulletin Penelitian. 9: 78-96.

Atman. 2006. Budidaya kedelai di lahan sawah Sumatera Barat. Peneliti Balai Pengkajian Teknologi Pertanian (BPTP). Jurnal Ilmiah Tambua Vol,V, No 3 SeptemberDesember 2006.

Badan Pusat Statistik. 2011. Data Produksi Kedelai Lokal. http://bps.go.id. Jakarta.

Bara AM, Chozin A. 2009. Pengaruh Dosis Pupuk Kandang dan Frekuensi Pemberian Pupuk Urea Terhadap Pertumbuhan dan Produksi Jagung (Zea mays L) di Lahan Kering. Makalah Seminar Departemen Agronomi dan Hortikultura Fakultas Pertanian Institut Bogor.

Budiarto. 2003. Biostatistik untuk Kedokteran dan Kesehatan Masyarakat. Jakarta: EGC.

Davies PJ. 1995. The plant hormone their nature, occurence and function. In Davies (ed.) Plant Hormone and Their Role in Plant Growth Development. Dordrecht Martinus Nijhoff Publisher.

Departemen Pertanian. 2012. Pedoman Teknis Pengelolaan Produksi Tanaman Kedelai.http://deptan.go.id/docupload/isi pedomantekniskedelai2012.

Fahmi N, Syamsuddin, Ainun M. 2014. Pengaruh pupuk organik dan anorganik terhadap pertumbuhan dan hasil kedelai (Glycine max (l.) Merril). Floratek 9: 5362, 53-62.

Follet RH, Murphy LS. 1989. Fertilizer and Soil Amandements. New Jersey PrenficsHell Inc.

Gaba VP. 2005. Plant growth regulator. In R.N. Trigiano and D.J. Gray (eds.) Plant Tissue Culture and Development. London: CRC Press. p. 87-100. 
Gardner 1991. Fisiologi Tanaman Budidaya.. Jakarta: Universitas Indonesia Press. (Terjemahan dari Physiology of Crop Plants oleh Herawati Susilo)

George EF. 1993. Plant propagation by tissue culture. Part 2 in Practice. England: Exegeticts Lim.

Humphries EC, Wheeler AW. 1963. Annu. rev. plant physiol. Dalam Fisiologi Tanaman Budidaya ed. Gardner F P , RB Pearce dan RL Mitchell. 1991. Terjemahan : Herawati Susilo. Jakarta: UI Press .

Johnson DS, Wang, Suzuki A. 1999. Edamame vegetable soybean for Colorado. In Janick, J. (Ed). Perspectives on New Crops and New Uses. Alexandria: ASHS Press

Kartahadimaja JR. Wentasari, Sesanti RN. 2010. Pertumbuhan dan produksi polong segar edamame varietas rioko pada empat jenis pupuk. AGROVIGOR 3(2): 131-137.

Lazureanu A. Diana M. Gogoasia MA. Poiana M. Harmanescu I. Gergen. 2007. Influence of NPK fertilization on nutritional quality of tomatoes. Faculty of
Food processing Technology. Banat's University of Agicultural Sciences and Veterinary Medicine. Buletin USAMVCN 64. Romania.

Lingga P, Marsono. 2000. Petunjuk Penggunaan Pupuk. Jakarta: Penebar Swadaya. $150 \mathrm{hlm}$.

Ningsih IM, Dwiastuti R, dan Suhartini. 2015 Determinan Efisiensi Teknis Usaha Tani Kedelai. Jurnal Manajemen \& Agribisnis. 2(5):216-225

Rukmana R, Yuniarsih. 1996. Kedelai, Budidaya dan Pascapanen. Yogyakarta: Penerbit Kanisius.

Sitompul SM, Guritno B. 1995. Analisis Pertumbuhan Tanaman. UGM-Press. Yogyakarta.

Suryana A. 2012. Pengaruh Waktu Aplikasi dan Dosis Pupuk Majemuk NPK pada Pertumbuhan dan Hasil Kedelai Varietas Grobogan. Universitas Lampung.

Widiastoety D, Nurmalinda. 2010. Pengaruh suplemen nonsintetik terhadap pertumbuhan planlet anggrek vanda. Jurnal Hortikultura 20(1):60-66. 